\title{
Effects of auxin and misting on the rooting of herbaceous and hardwood cuttings from the fig tree
}

\author{
Efeitos de auxina e nebulização no enraizamento de estacas herbáceas e lenhosas de \\ figueira
}

\author{
Cleiton Mateus Sousa ${ }^{2 *}$, Rubens Nei Busquet ${ }^{3}$, Marco Antônio da Silva Vasconcellos ${ }^{3}$ e Ricardo Motta Miranda ${ }^{3}$
}

\begin{abstract}
Propagation of the fig tree predominately uses hardwood cuttings obtained from pruning stock plants. With a view to optimising fig tree propagation, the effects of auxin and misting on the rooting of herbaceous and hardwood cuttings from the fig tree were evaluated. An experiment was set up in a $2 \times 2 \times 2$ factorial design, with two types of cuttings (softwood and hardwood), two levels of auxin (0 and $1000 \mathrm{mg} \mathrm{L}^{-1}$ indolbutyric acid) and two environments (with and without misting). Thirty days after starting the experiment, rooting, root length, sprouting and losses were all evaluated. The interaction of the type of cutting and the auxin was significant for rooting, sprouting, root length and cutting loss. Misting did not affect the variables analysed. In the absence of auxin, there was no difference between the type of cutting for rooting, length of root and sprouting, while the application of auxin $\left(1,000 \mathrm{mg} \mathrm{L}^{-1}\right)$ produced a reduction in these variables. The production of fig tree seedlings can be made from either softwood or hardwood cuttings and does not require the use of auxin or misting.
\end{abstract}

Key words: Fig tree. Auxin. Plant propagation. Cut.

RESUMO - A propagação da figueira predomina com o uso de estacas lenhosas obtidas após a poda de plantas matrizes. Visando otimizar a propagação da figueira, avaliou-se os efeitos da auxina e da nebulização no enraizamento de estacas herbáceas e lenhosas de figueira. Foi implantado um experimento em fatorial 2x2x2, sendo dois tipos de estacas (herbáceas e lenhosas), dois níveis de auxina (0 e $1.000 \mathrm{mg} \mathrm{L}^{-1}$ de ácido indolbultírico) e dois ambientes (com ou sem nebulização). Aos 30 dias após a implantação do experimento, avaliou-se o enraizamento, comprimento da radícula, brotação e perdas. A interação do tipo de estaca e auxina foi significativa para enraizamento, brotação, comprimento da radícula e perdas de estacas. A nebulização não interferiu nas variáveis analisadas. Na ausência de auxina não houve diferença entre os tipos de estacas para o enraizamento, comprimento da radícula e brotação, enquanto, a aplicação de auxina (1.000 $\left.\mathrm{mg} \mathrm{L}^{-1}\right)$ proporcionou redução para estas variáveis. A produção de mudas de figueira pode ser realizada a partir de estacas herbáceas ou lenhosas e dispensa o uso de auxina e nebulização.

Palavras-chave: Figo. Efeito da auxina. Propagação de plantas. Estaquia.

\footnotetext{
*Autor para correspondência

${ }^{1}$ Recebido para publicação em 21/09/2011; aprovado em 19/09/2012

Trabalho de Iniciação Científica, bolsista do CNPq

${ }^{2}$ Instituto Federal Goiano, Campus Ceres, Rod. GO 154, km 03, Zona Rural. Ceres-GO, Brasil, 76.300-000, sousacm@yahoo.com.br

${ }_{3}^{3}$ Departamento de Fitotecnia, Instituto de Agronomia, Universidade Federal Rural do Rio de Janeiro, BR 465, km 7, Seropédica-RJ, Brasil, 23.890-000,

rbusquet@ufrrj.br; masv@ufrrj.br, rmottam@ufrrj.br
} 


\section{INTRODUCTION}

In the propagation of the fig tree (Ficus carica $\mathrm{L}$.) the use of cuttings predominates. These are prepared from branches obtained when pruning that can be stored where they will finally be cultivated, or in a greenhouse in order to produce seedlings for subsequent transplanting.

Obtaining seedlings from bare roots through ligneous cuttings takes about a year, since the cuttings, rooted in winter will be transplanted to a permanent site only the following year. On the other hand, if rooted directly in the field, many fail when the plants take, and to compensate for this the use of two cuttings per hole is recommended (CHALFUN; HOFFMANN, 1997), thus increasing the amount of propagative material (NOGUEIRA et al., 2007).

The use of auxin has shown excellent results in increasing the fixation index in fig tree cuttings (IOP et al., 2008; LAJUS et al., 2007; RAMOS; LEONEL; DAMATTO JUNIOR, 2008). Most work with propagation is carried out in conditions of high humidity with intermittent misting, which allows no evidence of the actual effect of auxin.

The production of fig-tree seedlings at the place of cultivation reduces the costs of production, however in most cases they are not successful, with low rooting indices being obtained, even where auxin is applied. Whereas rooting from cuttings in a controlled environment can be considered as an excellent alternative, because it allows for greater efficiency and reduces the amount of propagative material used, producing uniform seedlings of a higher quality.

According to Pasqual et al. (2001), moisture is one of the fundamental external factors in encouraging rooting of the cuttings. Thus, more control over the humidity in the rooting environment can result in an improvement in the survival and rooting of the cuttings. Pio et al. (2006) found that a greenhouse supplied a good environment for the propagation of the fig tree from apical cuttings, doing away with the use of auxin.

For better utilization of the branches obtained during pruning, herbaceous cuttings have awakened interest in the production of fig tree seedlings, as they demonstrate excellent fixation with the application of auxin, in conditions of high humidity, however this technique can be costly for small producers, compromising commercial applications.

Hartmann et al. (1997) recommend that ligneous cuttings be collected when the vegetation is dormant and semiligneous cuttings be taken during the summer when the plants are in full vegetative development, considering herbaceous cuttings to be those from non-ligneous species.
For cuttings with rooting difficulties, such as the ligneous, the use of intermittent misting is recommended to reduce the air temperature and the rate of transpiration, as this maintains a film of water on the cuttings.

The success of rooting for basal cuttings is associated with the increased availability of carbohydrates. However, Light, Paiva and Landgraf (2007) found no significant effect among the cutting types when rooting the hydrangea. Whereas Dantas, Dutra and Kersten (1999), found that apical cuttings of the guava showed a higher percentage of rooting, as in the mombin, verified by Lima et al. (2002). Therefore the formation of adventitious roots on cuttings is seen to depend on several factors, it being necessary to define the appropriate conditions for each genotype studied.

The effects of auxin application and of misting on adventitious root formation were therefore studied on stem cuttings of the fig tree.

\section{MATERIAL AND METHODS}

The cuttings were taken from branches resulting from the pruning in July of stock plants of the fig tree of the variety valinhos purple, grown at Fazendinha Agroecológical of EMBRAPA Agroecológica in Seropédica, Rio de Janeiro.

The herbaceous cuttings were taken from the last third of the branch, discarding the last $20 \mathrm{~cm}$, while the ligneous cuttings were prepared from the middle and bottom portions of the branch. The cuttings were taken in such a way as to contain at least four buds, were about $20 \mathrm{~cm}$ long, with a bevelled cut on the bottom and a straight cut at the top.

The experiment was set up in a randomized block design, in a $2 \times 2 \times 2$ factorial consisting of two levels of indolebutyric acid ( 0 or $1,000 \mathrm{mg} \mathrm{L}^{-1}$ ), two types of cuttings (herbaceous and ligneous), two environments (with or without one minute of misting at 30 minute intervals), with four replications and 10 cuttings to each experimental unit.

For those cuttings destined for treatment with auxin, the base was immersed for five seconds in a solution of indolebutyric acid of $1000 \mathrm{mg} \mathrm{L}^{-1}$ and then inserted approximately $1 / 3$ of their length into a plot which contained a substrate of washed river-sand, either with or without misting under greenhouse conditions.

At 30 days after the start of the experiment, the percentage of cuttings with shoots, roots or losses (dead and/or rotting) were evaluated. The data were analyzed by ANOVA, and the averages compared with the Tukey test at $5 \%$. 


\section{RESULTS AND DISCUSSION}

The treatments used resulted in rooted fig tree cuttings, with shoots and the potential for seedling production. The highest rooting percentages were obtained about 30 days after the beginning of the experiment.

Rooting, sprouting and root length all showed significant differences depending on the auxin and type of cutting, with significant interaction between these factors.

In the presence of auxin, the herbaceous cuttings showed $68.3 \%$ rooting, while the percentage for the ligneous was only $23.3 \%$. In the absence of auxin, there was $88.3 \%$ rooting for the herbaceous cuttings and $76 \%$ for the ligneous, with no significant differences (Figure 1). Pio et al., (2003) reported that cuttings prepared from the apical portion have good rooting indices and can be an excellent option for producing seedlings in a greenhouse.

Applying auxin helps to increase rooting in cuttings of some plants (DAVIES, 1995), however, in cuttings from the fig tree, Pio et al., (2006) reported that application of auxin becomes unviable, since the percentage obtained in relation to the control was only $7.92 \%$. In the present investigation however, the application of auxin reduced the percentage of rooting, being more significant in the igneous cuttings. In stem cuttings of the pitaya, the application of ANA did not influence the formation of adventitious roots (SANTOS et al., 2010), indicating that the cuttings already contained those factors necessary for adventitious root formation, whereas Ferreira et al. (2010) observed that rooting in cuttings from the manioc, depends on the diameter, with better results in those cuttings with a diameter greater than $1.0 \mathrm{~cm}$.

This divergence in the responses for adventitious rooting found between different species and growing conditions, can be associated with other factors involved in the process, such as the age of the tissue used, reserves, hormonal balance in the tissue, cell sensitivity, the presence of other molecules in the tissue and the nutritional and phytosanitary conditions of the mother plant.

The effect of the auxin is associated with the endogenous auxin content present in the rooting zone during the event (FIRECREST et al., 2003) and its application has been adopted to increase the endogenous levels and promote rooting, which suggests that the formation of roots requires an optimal level of this molecule. Applying auxin enhances rooting only when the endogenous level of auxin is the sole limiting factor to the formation of adventitious roots (DAVIES et al., 1995), suggesting that in the fig, auxin is not a limiting factor in adventitious-root formation from cuttings.

The fact that no significant differences are seen with the presence or absence of misting suggests that the changes in climatic conditions inside the greenhouse were sufficient to provide suitable conditions for rooting. Pio et al. (2003) did not achieve rooting in cuttings of the fig buried up to $2 / 3$ of their length in the substrate when they were kept on screens or under the sun, whereas in a greenhouse, rooting was around $65 \%$.

In herbaceous cuttings, auxin did not affect budding, while in the igneous, the presence of auxin reduced the percentage of budding (Figure 2). However, Pio et al. (2006) found no significant difference between levels of auxin in the percentage of buds. There was a positive correlation with root length of $82.58 \%$ in budding and of $91.20 \%$ in rooting, indicating that the growth of buds contributes to adventitious root formation and growth. Buds are thought to be sites of auxin synthesis

Figure 1 - Percentage of rooting of fig tree cuttings as a function of the interaction of the cutting type and auxin concentration. Seropédica, Rio de Janeiro

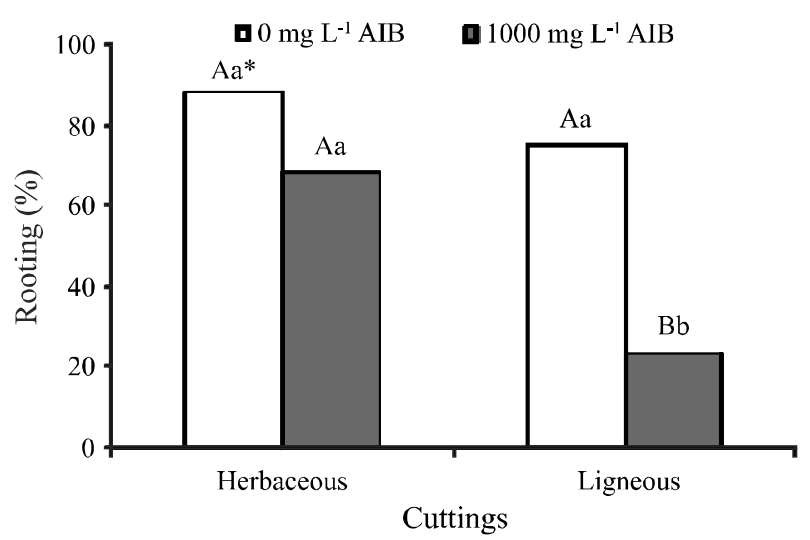

* Capital letters compare auxin concentrations for each type of cutting and lowercase compare cutting type within each concentration of auxin

Figure 2 - Percentage of budding in fig cuttings as a function of the interaction of the cutting type and auxin concentration

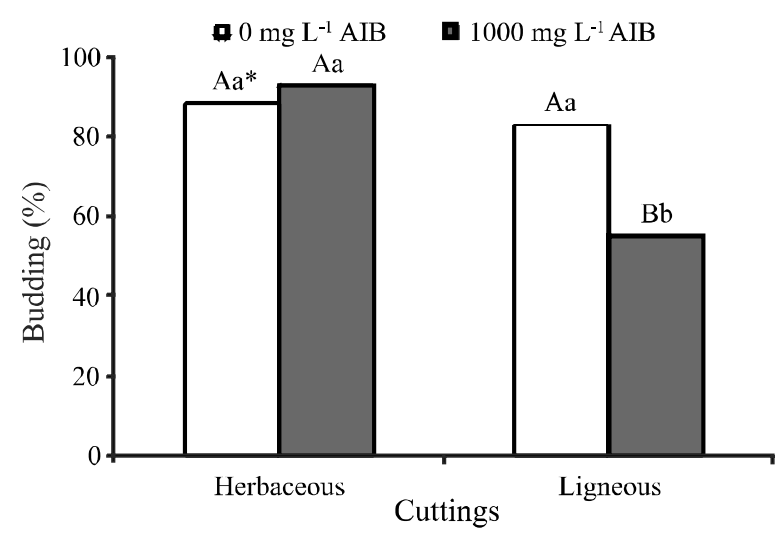

* Capital letters compare auxin concentrations for each type of cutting and lowercase compare cutting type within each concentration of auxin 
(TAIZ; ZEIGER, 2004) and co-factors responsible for rooting (HARTMANN et al., 1997), which are displaced towards the base of the cuttings: this could increase the concentration of these factors at the base of the cutting and encourage the formation of adventitious roots.

The ligneous cuttings presented a lower rooting index (Figure 1) and a higher rate of loss when treated with auxin (Figure 3 ). In the herbaceous cuttings, an $8.3 \%$ loss was seen in the absence of auxin and $3.33 \%$ in the presence of auxin. However, in the ligneous cuttings, the response was reversed, where the lowest loss was observed with the absence of auxin (5\%) and the highest in the presence of auxin $(25 \%)$. This suggests that each type of cutting has its own specific conditions, and in ligneous cuttings, the tissues are more sensitive to auxin, since in the absence of auxin, rooting did not differ from the best result obtained, and the auxin reduced rooting (Figure 1) and resulted in greater losses (Figure 3).

Figure 3 - Percentage of losses in stem cuttings of the fig as a function of auxin and cutting type

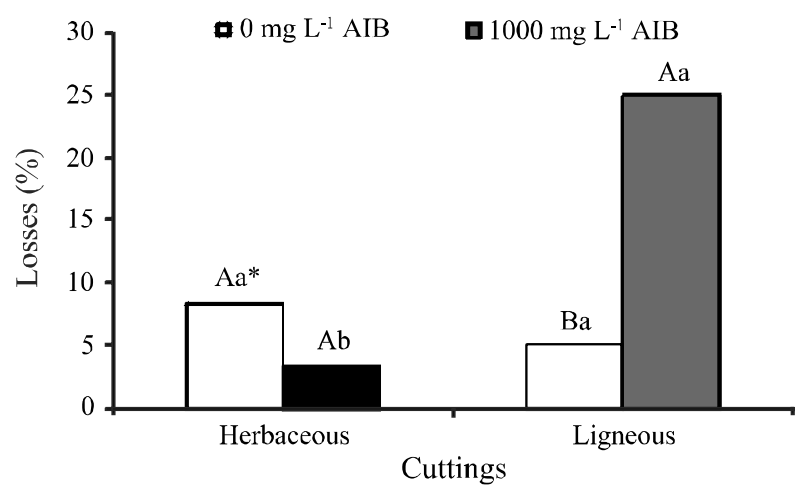

* Capital letters compare auxin concentrations for each type of cutting and lowercase compare cutting type within each concentration of auxin

It was found that for both rooting and the budding, the combination of igneous cuttings with the application of auxin resulted in a smaller root-length in cuttings of the fig tree. The auxin reduced root length (Figure 4), showing again that the tissue is more sensitive to the application of auxin however in herbaceous cuttings this effect was not seen. Perhaps among the types of cutting, differences exist between tissue sensitivities and not the hormonal levels, since herbaceous cuttings displayed rooting similar to the igneous in the absence of auxin. Pio et al. (2004) observed that applying auxin resulted in a linear decrease in root length.
Figure 4 - Effect of auxin and cutting type on the root length in fig-tree cuttings

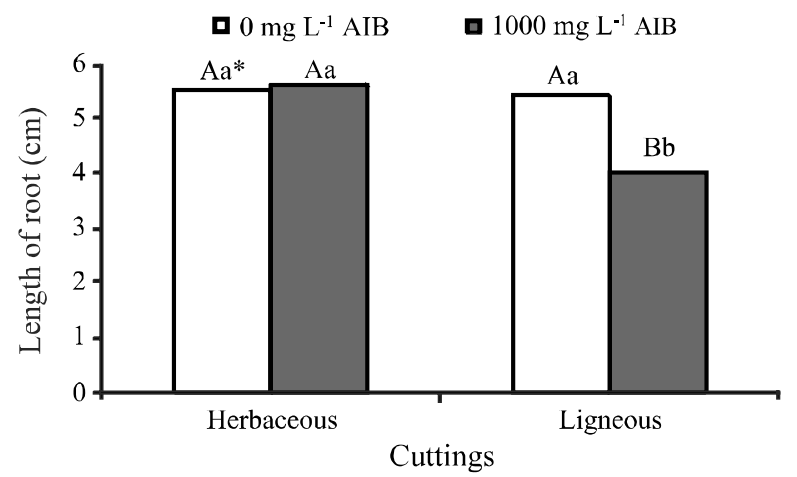

* Capital letters compare auxin concentrations for each type of cutting and lowercase compare cutting type within each concentration of auxin

\section{CONCLUSIONS}

1. Auxin and misting did not increase the rooting of herbaceous and ligneous cuttings of the fig tree;

2. Herbaceous cuttings presented better results for propagation of the fig tree.

\section{REFERENCES}

BISBIS, B. et al. Restart of lignification in micropropagated walnut shoots coindides with rooting induction. Biologia Plantarum, v. 47. n. 10. p. 1-5, 2003.

CHALFUN, N. N. J.; HOFFMANN, A. Propagação da figueira. Informe Agropecuário, , v. 18, n. 188, p. 9-13, 1997.

DANTAS, A. C. M.; DUTRA, L. F.; KERSTEN, E. Influência do Etefon e do tipo de estaca no enraizamento de goiabeira (Psidium guajava L.). Revista Brasileira de Agrociência, v. 5, n. 1, p. 19-21, 1999.

DAVIES, P. J. The plant hormones concept: concentration, sensitivity and transport. In: DAVIES, P. J. (Ed.) Plant hormone: physiology, biochemistry and molecular biology. Dorderecht: Kluwer Acad. Publi., 1995. p. 13-38.

HARTMANN, H. T. et al. Plant propagation principle and practices. 6. ed. New Jersy, USA: Prentice-Hall, 1997. 770 p.

LAJÚS, C. R. et al. Ácido Indolbutírico no Enraizamento de Estacas Lenhosas de Figueira (Ficus carica L.). Revista Brasileira de Biociências, v. 5, v. 2, p. 1107-1109, 2007. Suplemento.

LIMA, A. K. C. et al. Propagação de cajarana (SPONDIAS SP.) e cirigüela (SPONDIAS PURPUREA) por meio de estacas verdes enfolhadas, nas condições climáticas de Mossoró-RN.

Caatinga, v. 15, n. 1/2, p. 33-38, 2002. 
FERREIRA, L. E. et al. Diâmetro de estacas e substratos na propagação vegetativa de maniçoba, Manihot glaziovii Muell. Arg. Revista Ciência Agronômica, v. 41, n. 3, p. 393-402, 2010.

LUZ, P. B.; PAIVA, P. D. O.; LANDGRAF, P. R. C. Influência de diferentes tipos de estacas e substratos na propagação assexuada de hortênsia [Hydrangea macrophylla (Thunb.) Ser.] Ciência e Agrotecnologia v. 31, n. 3, p. 699-703, 2007.

NOGUEIRA, A. M. et al. Propagação de figueira (Ficus carica L.) por meio de estacas retiradas durante o período vegetativo. Ciência e Agrotecnologia, v. 31, n. 3, p. 914-920, 2007.

PASQUAL, M. et al. Fruticultura comercial: propagação de plantas frutíferas. Lavras: UFLA/FAEPE, 2001. 137 p.

PIO, R. et al. Enraizamento de estacas apicais de figueira em diferentes acondicionamentos e ambientes distintos. Revista Brasileira de Agrociência, v. 9, n. 4, p. 357-360, 2003.

PIO, R. et al.. Enraizamento de estacas radiculares de figueira 'roxo de valinhos' tratadas com AIB e dois métodos de imersão. Scientia Agraria, v. 9, n. 1, p. 111-115, 2008.
PIO, R. et al. Enraizamento adventício de estacas apicais de figueira e desenvolvimento inicial das plantas no campo. Ciência e Agrotecnologia, v. 28, n. 1, p. 213-219, 2004.

PIO, R. et al. Propagação de estacas apicais de figueira: diferentes ambientes, ácido indolbutírico e tipo de estaca. Ciência e Agrotecnologia, v. 30, n. 5, p. 1021-1026, 2006.

RAMOS, D. P.; LEONEL, S.; DAMATTO JÚNIOR, E. R. Avaliação da época de estaquia e uso de bioregulador no enraizamento de estacas de figueira. Revista Brasileira de Fruticultura, v. 30, n. 3, p. 748-753, 2008.

SANTOS, C. M. G. et al. Substratos e regulador vegetal no enraizamento de estacas de pitaya. Revista Ciência Agronômica, v. 41, n. 4, p. 625-629, 2010.

TAIZ, L.; ZEIGER, E. Fisiologia vegetal. 3. ed. Porto Alegre: Artmed, 2004. 719 p. 